\title{
NEW TOOLS FOR NEW URBAN SPACES? ANALYSES OF PLANNING AND PARTICIPATION TOOLS AND THEIR PERFORMANCE IN (POST)TRANSITIONAL PERSPECTIVE
}

\author{
'Anatolii MELNYCHUK, ${ }^{2}$ Olena DENYSENKO, ${ }^{3}$ Pavlo OSTAPENKO
}

\author{
'Taras Shevchenko National University of Kyiv, Ukraine \\ ${ }^{2}$ Ukrainian Researchers Society \\ 'melnychuk@knu.ua2denysenko.olena.o@gmail.com, ${ }^{3}$ ostapenkopavlo@gmail.com
}

\begin{abstract}
For a long time post-socialist countries served as a space for interaction between multiple transformations, urban policy changes and urban planning adjustments on the one hand, and challenging institutional and socio-cultural legacy, on the other. What are the outcomes of these interactions and how the urban space is changing? How effective are traditional ("old") and newly established planning and participation tools? To what extent does the current system meet the expectations of different stakeholders? These are the main issues to discuss in the paper. For this aim we use the experience of Ukrainian planning system changes in (post) transitional perspective, focusing on several planning and participation tools and their performance both on the national and local level.

The impact of the main planning and participation tools on the urban transformations in Ukraine is critically considered in the paper, discussing their outcomes from different perspectives. The local context of using particular tools is discussed through the cases of two cities - Kryvyi Rih and Kherson; this allows to trace the logic of the planning process and practices of urban restructuring, notably by using the tools of participation. Using in-depth interview data,the paper is aimed at revealing how different stakeholders perceive the main planning and participation tools as well as evaluate their effectiveness. Thus, we rethink the changes of planning and participation tools in (post)transitional perspective, their role in urban development processes, their performance in various local contexts and also their compliance with the declared goals and interests of different stakeholder groups.
\end{abstract}

Key words: post-socialist countries, transition, planning, participation, urban spaces, Kryvyi Rih, Kherson.

DOI: https://doi.org/10.17721/2413-7154/2021.85.11-22

UDC: $911.3: 711.4$

Received: March 2, 2021.

Accepted: March 24, 2021.

\section{НОВІ ІНСТРУМЕНТИ ДЛЯ НОВОГО МІСЬКОГО ПРОСТОРУ? АНАЛІЗ ІНСТРУМЕНТІВ ПЛАНУВАННЯ, УЧАСТІ ТА ÏХ ДІЄВОСТІ У (ПОСТ)ТРАНЗИТНІЙ ПЕРСПЕКТИВІ}

\author{
'Анатолій МЕЛЬНИЧУК, ²Олена ДЕНИСЕНКО, ${ }^{3}$ ПавЛо ОСТАПЕНКО \\ 'Київський начіональний університет імені Тараса Шевченка, Україна \\ "ГО "Товариство Дослідників України" \\ 'melnychuk@knu.ua2denysenko.olena.o@gmail.com, ${ }^{3}$ ostapenkopavlo@gmail.com
}

\begin{abstract}
Анотація: Тривалий час постсоціалістичні країни $є$ простором взаємодії множинних трансформацій, перетворень міської політики, переформатування основних інструментів, з одного боку, та складної інституційної і соціально-культурної спадщини, з іншого. Яким $є$ результат цієї взаємодії та як змінюється міський простір; наскільки дієвими є традиційні “старі" та нові інструменти планування та участі (партисипації), що з'явилися в останні роки; якою мірою сформована система задовольняє очікування різних стейкхолдерів - основні питання, на які покликана відповісти дана стаття. 3 цією метою ми аналізуємо перетворення системи планування в Україні у (пост)транзитній перспективі, спираючись на кілька основних інструментів планування та участі та аналіз їхньої дієвості, як на національному, так і на локальному рівні.

У статті критично розглядаєтьсявплив основних планувальних та учасницьких інструментів на процеси перетворення міського простору в Україні, представляючи їх результати з різних позицій. Спираючись на кейси двох міст - Кривого Рогу та Херсона - відображено локальний контекст використання різних інструментів, що дозволяє прослідкувати логіку планувального процесу та практики перетворення міського простору, зокрема, шляхом використання учасницьких інструментів. На основі матеріалів глибинних інтерв'ю ми намагаємося відобразити, як різні стейкхолдери сприймають основні інструменти планування та партисипації, а також оцінюють їх дієвість. Таким чином, стаття переосмислює перетворення системиінструментів планування та участі у (пост)транзитній перспективі, їхню роль у перетворенні міського простору та прояв цих інструментів у різних локальних контекстах, а також їхню відповідність декларованим цілям та інтересам різних груп стейкхолдерів.

Ключові слова: постсоціалістичні країни, транзитність, планування, партисипативність, міський простір, Кривий Ріг, Херсон.
\end{abstract}




\section{Introduction}

The transition period from socialism to the market, experienced by the Central and Eastern European countries, was followed not only by the dramatic developments in the socio-economic relations, but also radical social and political transformations, resulting in changing the concepts of common good, public policy, urban governance and urban development. This led to the destruction and subsequent fundamental overhaul of the established concepts and conditions for urban development and urban governance, major changes and restructurings of urban spaces almost everywhere. However, in practice, the transformation of urban space in Ukraine was mostly chaotic and disordered for years, therefore the rethinking of the strategy for urban transformations and the role of individual actors in this process lasted over the past decades. It is in this context that there structurings of institutions and tools for urban development and planning were carried out, along with the concepts about them.

This paper aims at rethinking the system of traditional "old" tools for urban transformations, especially in the field of urban planning, and relatively new tools based on participatory governance ideas (Fung \& Wright, 2003; Fischer, 2012), collaborative planning (Healey, 1999; Innes \& Booher, 2018) and place-making processes (Friedmann, 2010; Cilliers \& Timmermans, 2014) under transition and post-transition stages. The paper aims at furthering the critical reconsideration of the main urban planning and participation tools in Ukraine and their impact on the urban transformations, offering the views of the main actors involved, both on the particular tools and their performance, and also the process of urban transformation and its effectiveness. Thus, the paper is intended to answer the questions: to what extent do the existing tools of planning and participation contribute to the transformation of urban space; how effectively they complement each other, developing a single system; in which direction do they change and to what extent are these changes able to ensure the needs of various actors to transform the urban space, thus establishing a range of certain (im)balances?

Despite the discussions on the completion of post-socialist transformations and rethinking of them (Tsenkova, 2006; Sýkora \& Bouzarovski, 2012; Golubchikov et al., 2014; Ferenčuhová \& Gentile, 2016; Hirt et al., 2016; Мезенцев \& Денисенко, 2018), the role of the institutional legacy of the transition period remains noticeable in many aspects. Urban planning is one of such areas, since the planning institutions are "culturally embedded in the overall process of economic, social and political transition" (Tsenkova, 2014); therefore, all countries of the region were supposed to restructure the planning system during the transition period substantially (for experiences of planning systems restructurings see Golubchikov, 2004; Hirt, 2005; Sýkora, 2006; Vujošević \& Nedović-Budić, 2006).

It is worth noting that the very idea of planning was largely discredited during the Soviet period by its close connection to the ideological imperatives (Grava, 1993; Hirt \& Stanilov, 2009; Палеха \& Олещенко, 2016). This led to long-term negative consequences for planning as a field of activity, where the transition period was accompanied by "broad legitimacy crises of planning" (Hirt \& Stanilov, 2009), which was mostly perceived (and sometimes is being perceived) as a relic of the socialist period. From these perspectives debates on the impact of socialist legacy on the transformation of the planning tools and the whole planning process still remain relevant; while searching the new content of the urban planning in a changing environment is an important task for government and society in the face of multiple challenges accompanying urban transformations.

The period of transition as defined by E. Golovakha and N. Panina, was accompanied by the process of socalled "deinstitutionalization" - "the destruction of institutional entities, changes of social rules and apparent (or hidden, latent) rejection of institutional requirements to social behavior" (Головаха \& Панина, 2001). The multi-layered system of urban governance and urban planning encountered these processes in a similar way; in fact, the new institutions and tools in the field of urban planning were developed. This process has been pursued more intensively in Ukraine since the second half of the 1990s, when the updating of regulatory framework in the field of urban planning and urban development began.

In this paper we analyze the institutional context of the urban planning system in relation to its multidimensional transformations and adaptations in line with the new trends of democratization, participation, and collaboration, as well as the results of these transformations and adaptations through the vision of the main actors involved. To a large extent, it is also rethinking of the changes in the planning system in Ukraine during the transition period, developed tools and balances established between the main actors. Echoing O. Golubchikov, the transformation of the planning system in market conditions "has introduced a new urban context - new actors and new rules of the game, new challenges, and new structures of decision-making" (Golubchikov, 2004). The new rules and structures, tools and institutions therefore should be tested for compliance with the strategic priorities of urban transformations in today's reality and the interests of key stakeholder groups.

All the key changes of the post-Soviet planning system of recent decades were marked by several trends, which included: (1) deidelogization - the process of ridding the planning system of ideological and political imperatives from the Soviet past; (2) democratization the process of increasing the openness and transparency of the institutions, tools, regulatory procedures, and separate documents; (3) decentralization - the process of redistribution of power between different levels of decision-making in the field of urban planning and urban development. These changes actually were resulted from fundamental social transformations and have reflected the increasing demand for restructuring of public institutions and implementing the new forms of governance: the people "come to think about development and governance" (Healey, 2010) in a different way. 
Analysing cities as "sites of serial policy failure" (Peck et al., 2009), many current challenges encountered by post-transition countries can be seen as common concerns for any country when facing urban restructuring needs and expectations for collaborative governance. Such concerns to a large extent are related to ability of urban planning system and particular tools to meet the demands for effective urban governance and planning in the face of multiple challenges. At the same time, interpreting of "distinctive national, regional and local contexts, defined by the legacies of inherited institutional frameworks, policy regimes, regulatory practices and political struggles" (Peck et al., 2009) in the light of urban restructuring needs play a cruicial role for understanding the main existing barriers in this regard.

In order to interpret both the national and local context of urban restructuring in Ukraine in posttransitional perspective, this study is based on the analysis of a range of urban planning and participation tools and their changes, on the one hand, and in-depth interviews with different stakeholders, drawing on the experience of two cities - Kherson and Kryvyi Rih, on the other hand. Involving in-depth interviews from two case-cities allows to reflect different local contexts and, consequently, the views of different actors on the planning and participation tools as well as their performance. Consequently, the analysis reveals various practices of urban planning and participation, implemented by local actors; typical distortions and violations when realizing urban planning policy and also development of some new local tools and initiatives, thereby providing a view on performance of the planning and participation tools.

This paper starts with an analysis of the main planning and participation tools related to urban transformations, in particular, their normative framework and the main trends of their numerous adjustments under transition and (post)transition period. Then, using the cases of two cities, it looks at how the main actors, involved in urban restructurings, perceive the particular tools, taking into consideration their functions and goals they are expected to achieve. Finally, the paper reinterprets the system of tools developed through the multiple practices from the perspective of their impact on urban transformations and balances established between involved actors, offering several criteria for estimation the performance of particular tools.

\section{Planning tools under the new conditions of (post)transition}

Recognizing that planning "is always a product of particular social relations" (Golubchikov, 2004) and "is always historically grounded" (Friedmann, 2005), not surprisingly, the new socio-economic reality and new social context of transition required changesin approaches to planning, planning institutions and the tools themselves. However, this process has proceeded much slower than expected and required significant efforts in overcoming the institutional and socio-cultural legacy of the previous era. Therefore, changes in the approaches to planning and dynamic adjustments the tools themselves continued in parallel to the rethinking of planning and its functions. In this regard, the negative image of planning and spatial planning in particular was one of the major barriers to overcome under which "urban planning and policy was perceived as a contradictory to the market" (Sýkora, 2006).

"...Post-communist planning has been generally weak, passive and reactive" (Hirt \& Stanilov, 2009), it contained numerous signs of communist ideology inherited from the Soviet times (Маруняк, 2014), thus the planning had to "re-establish itself as an important societal function" anyway (Hirt \& Stanilov, 2009) or even be "reinvented in a reinvented state" (Van Assche et al., 2010). This process began in the region of Central and Eastern Europe in the 2000s (Hirt \& Stanilov, 2009), with establishing of a new institutional framework for planning and changing of its principles and objectives. Planners started to address less known issues and challenges, in particular "learned to pay attention to urban competitiveness, cohesion and sustainability, learning that these issues are high on the European urban agenda" (Sýkora, 2006).

In Ukraine, as in other countries of CEE, a new institutional framework for urban planning and development was generally established in the early 2000s. In 2000, the Law of Ukraine on Planning and Development of Territories was adopted, where "legal and organizational grounds for planning, building and otherwise utilizing of territories" were set (Закон України Про планування і забудову..., 2000). This Law, as declared, was aimed at "ensuring sustainable development of settlements". In 2002, the Law of Ukraine on the General Scheme for Planning the Ukrainian Territory was adopted, approving the General Scheme and providing the mechanisms for its further implementation and monitoring. It was expected, that establishing "priorities and conceptual solutions to planning and using territory of the country" will contribute to ensuring the sustainable development of settlements. Generally, the period of the late 1990s and early 2000 s is marked by focusing mainly on addressing the challenges at the national and regional levels, typical for a country in the post-Soviet reality, requiring rethinking of spatial development on a completely different scale and implementing completely different regional and planning policies.

Since the 1990s the institutional framework in urban planning has been regularly updated and planning tools transformed, thus contributing to involvement new actors and improving the regulations in this field. Although the planning process as much as its results remained quite secret, but it must be recognized that some legislative changes were intended to open up the window. To illustrate how the overall process of legislative developments in urban planning looked in (post)transitional perspective the most important documents could be mentioned. In 1992 the State building regulations (DBN) "Planning and development of urban and rural settlements" were adopted and remained in force to 2019, when new building regulations were adopted. In order to deal with the composition and content of the master plan as a main planning tool the building regulations were developed first in 1997 and later in 2012, and also for a detailed plan of the territory - in 2009 and 2012 respectively. In 2011 the new tool in the field of urban planning - zoning - 
was introduced by the Law of Ukraine "On Regulation of City Planning Activity", which had replaced the Law of Ukraine "On Planning and Development of Territories", adopted in 2000. The adoption of the Law in 2011 resulted from several unsuccessful attempts to develop a single urban planning code. As a result, legal provisions regulating various aspects of urban planning activities at the moment are scattered between six different Laws of Ukraine - "On the Principles of Town Planning" (1992), "On Architectural Activity" (1999), "On the General Scheme for planning the Ukrainian territory" (2002), "On comprehensive reconstruction of Blocks of Buildings (Micro-districts) of the Outdated Residential Housing Stock" (2006), "On Construction Regulations" (2009), "On Regulation of City Planning Activity" (2011). Such a scattering of provisions between different legal actsto a certain extent indicates to ongoing transitional processes in the field of urban planning and development, since the efforts to integrate the provisions governing one process into a single code and develop the integrated approaches to urban policy failed owing to complicated interactions between all stakeholders concerned.

One of the above-mentioned laws - Law of Ukraine "On the Principles of Town Planning", which "determines the legal, economic, social and organizational principles of town planning" (Закон України Про основи містобудування, 1992) although had been adopted in 1992, it still in force. Particular attention hereneeds to be focused on the term "town planning" (town-construction, if reproducing Ukrainian term mistobuduvannia word for word (equivalent to gradostroitelsvo in Russian)), which is still officially used as the key notion in Ukrainian planning. According to the Law, town-planning (or townconstruction, if literally) is "purposeful activity of state bodies, bodies of local self-government, enterprises, establishments, organizations, citizens, unions of citizens related to creation and maintenanceof full value living environment" (Article 1, Закон України Про основи містобудування, 1992). In fact, the concept of "townconstruction" and its content (despite some modernization) largely reflects the transitional character of urban planning and urban governance (both by name and by essence), and contains a strong imprint of the past era. On the one hand, "establishments, organizations, citizens and unions of citizens" together with the state and local selfgovernment bodies, according to the Law, are considered as actors in creating the living environment. On the other hand, the interpretation of urban planning ("townconstruction") as a result of the activities of state bodies, in particular purposeful activities designed to achieve certain goals still reflects the core idea of Soviet planning and governance. However, in transitional reality the objectives of planning and therefore the role of particular planning toolshave changed significantly, facing with intense urban transformations and threats of polarization, fragmentation and other negative phenomena. This, in turn, requires both the new conceptual frameworks in planning, and relevant content of urban planning and urban policy tools.

Three main groups of tools (Fig. 1) currently influencing urban transformations and restructurings can be considered: tools mainly oriented towards planning, public participation and regulation of urban development. Each of them, in fact, reflects different dimensions and stages of urban governance and planning process, forms of engagement and actors involved, character of interactions between the actors and their responsibilities. The planning tools include both well-known tools that have been used for decades in the field of planning, such as master plan and detailed plan of the territory, and also relatively new, such as municipal zoning, urban development strategy, concept of integrated urban development, and other tools related primarily to the purpose of increasing the effectiveness of planning and also implementation the goals of integrated development. While introducing the "new" tools reflects the need to respond the multiple transformations and other challenges, in particular, the enhancement of various actors in the restructuring of urban space, including civil society and expert community, the "old" tools also could not escape adjustments. To reflect this, several planning tools are analyzed below in terms of their role in the process of urban restructurings in (post)transitional reality.

Whereas in Soviet times the master plan, along with other tools, was primarily considered as a "mechanism for the physical implementation of state goals" (Hirt \& Stanilov, 2009), in post-transition perspective the master plan had to provide a completely different task - to propose a valid strategy for long-term spatial development of the city. Since the Soviet master plans were essentially focused on the conception of "location and growth" (of resources, people, infrastructure, etc.), the transition to the conception of "creating and development" required considerable efforts and time, therefore the new conception could not be implemented for several years, it required decades both for rethinking and implementation.

The definition of the master plan in the Law of Ukraine adopted in 2000 (Закон України Про планування..., 2000) and current Law in 2020 (Закон України Про регулювання, 2011) remains unchanged: it is "planning documentation that defines the principal decisions for urban development, planning, construction and other use of the territory of settlements", designed to "substantiate the long-term planning and development strategy". In practice the "long-term planning strategy", ironically, can be viewed from the Soviet perspective: we estimate that about a quarter of all cities (mainly small towns) have master plans developed before 1991. At the same time, about a quarter of cities have master plans approved after 2011 - in completely new socio-economic reality and conditions. These are mostly (but not only) big and medium-sized cities (so-called cities of regional significance).

The master plan validity period is typically about 20 years or even more (according to current legislation it is not time-restricted), that in transition reality means radical changes in urban development and causes criticism about the planning tools and planning itself. A major criticism is the relevance of master plans, their compliance with the existing conditions and the real situation, their ability to respond to the needs of urban renewal and investment plans and to balance the interests of all actors concerned. Quite often, master plans are becoming obsolete once they are approved, as this process could take years due to 
underfunding and other reasons. Therefore, it is difficult in such circumstances to expect an elaboration of successful spatial strategy in the master plan and its transformation into the real tool of urban development. This situation forces to look for alternatives both in terms of updating the types of planning documentation (introducing the new tools), changing the master plan itself, and supplementing the formal tools with new informal ones.

Municipal zoning is a "planning documentation which defines the conditions and restrictions on the use of the territory for urban development needs within certain zones" (Закон України Про регулювання..., 2011) and belongs to the new tools in urban planning that could be elaborated both as a part of the master plan, and as a separate type of planning documentation, which, however, should be agreed with the master plan. In practice planners do not always manage to ensure consistency between different types of planning documentation, sometimes leading to opposition between the actors, which is accompanied by allegations of legitimizing the illegal developments and use of the territory contradicting the master plan. Since zoning is relatively new tool (introduced by the Law of Ukraine in 2011),we estimate that only about one third of Ukrainian cities have elaborated and approved zoning plans.

Consequently, the planning tools in transitional reality have been significantly transformed to ensure their compliance with the new paradigms of urban development and urban governance, passing a long way of institutional changes. In the following parts we will consider to what extent planning tools are able to address the challenges of urban transformations as well as their weakness in this regard and also look at how the various actors involved interact with the main tools, assess their performanceas well as their ability to meet the needs.

\section{Participation tools under the new conditions of (post)transition}

Public participation and citizen engagement in urban transformations and urban planning have come a long and difficult way in Ukraine as one of the postcommunist countries. In this regard there is left a rather specific legacy from the Soviet past, related to the low social activity and low interest in urban planning issues. In the Soviet system of governance this was a matter of exclusive competence of the state bodies and in part local authorities, thereby rethinking this stereotype so far seems to be a challenging task for most post-socialist countries. Istenič \& Kozina in their research on how postsocialist cities encourage the involvement into decisionmaking basing on five different municipalities of CEE (Istenič \& Kozina, 2020) "revealed that participatory planning remains a great challenge in a post-socialist urban context" even now.

For a long time in post-Soviet countries participatory governance and planning due to a number of circumstances, was not considered a priority both for the state and for the citizens: "Often, people do not care, and rank planning low on their priority list" (Van Assche et al., 2010). This affected the public demand for both the quality and priorities of urban transformations and also demand for being engaged in these processes as well as requirement for the tools facilitating citizen engagement. Development of participatory tools in Ukraine generally continues to proceed in fits and starts, being closely related to the political situation and reforming institutions in planning, construction and related fields, along with increased public monitoring of local authorities' decisions. At the same time, the overall context of increased demand for openness and transparency in the activities of different agencies remains unchanged as well as awareness-raising, enhancing the participation and tools encouraging it. While a decade ago Hirt \& Stanilov in their report assessed the state of public participation in Central and Eastern Europe as being placed in-between levels 2 and 3 of Arnstein "ladder" (Hirt \& Stanilov, 2009), but describing the current state of affairs in Ukraine, we may note that quite often citizens are informed of plan-making, which corresponds to the third level of public participation ladder, and in some cases citizens are even consultants, when transforming urban spaces, and "are directly involved in plan-making", which corresponds to the fourth step. At the same time, this should not create the illusion about existing state of affairs with overall transparent citizen engagement in urban restructurings process as it is frequently declared, while in practice citizen engagement is more often used as a tool to legitimize the contentious decisions and also a tribute to the changing political culture or even as an imitation of the public dialogue between actors involved, resulting in numerous conflicts when urban spaces are transformed (for example see Neugebauer et al., 2020).

The overall trend of the last decades, related to strengthening the communicative approach in planning and "redefinition of planning in collaborative terms" (Gualini \& Bianchi, 2015), in turn, affects the tools linked to urban transformations. However, in the (post)transitional reality, establishing communicative tools and practices as well as any other interactions between the actors is being developed in a specific way, taking into consideration that each actor over and over again realizes, re-estimates and re-establishes their role in the urban restructurings and modernizations under regularly changing circumstances. Therefore, the actors' understanding of the urban transformations evolve quite rapidly, and practices which were common and acceptable some time ago, today could be considered inappropriate. Also it is entirely clear that different actors mainly have "different understandings of democratic politics" (Van Wymeersch et al., 2019) at this stage and values behind the notion of urban restructuring, therefore they argue for respective adjusments in urban planning and restructuring policy. The general climate of such adjustments can be interpreted as a part of the "postcommunist culture" (Durnová, 2021), which, however, manifests itself quite differently in different institutional contexts, reflecting in such a way deep-rooted attitudes to planning and restructurings. Therefore, the development of tools for participation and collaboration is related to rethinking the interactions between all parties involved in planning and transformations, as well as their vision of acceptable outcomes of these processes. 
Although there has been a broad discussion on the importance of increasing public participation and tools encouraging it, but balancing interactions between the main actors in transitional reality seems rather complicated process. Each time space is producing as a result of interactions under slightly different conditions, when a lot of tools are somehow modified. Therefore, a lot of urban spaces developed or changed in times of transition mirror the constituted balances between the interested parties very clear, as well as their evolution. These spaces together with reflected practices and behaviors are often criticized by many experts and activists for concepts used and disbalances embodied, thereby making the "institutional gaps" (Головаха, Панина, 2001) and other weaknesses particularly evident and contributing to the rising demand for publicity and collaboration.

The publicity of state agencies and local authorities, making decisions in urban planning and development became one of the crucial trends in recent years,shaping the agenda and facilitating modifications of the planning and participation tools. Growing publicity both contributes to changing the planning tools, increasing their accessibility, timeliness, along with interest in them and also promotes the emergence of new tools, particularly the tools of e-democracy. Although the latter are not directly related to urban planning, in practice they are largely focused on urban development issues. This is taking place in a variety of ways: by establishing reliable facts and increasing accessibility of information that may be of public interest; by involving interested parties in various forms of collaboration; by increasing public engagement and interest, and, therefore, the emergence of public debate on urban transformations and urban planning, and subsequently their enhancement.

The main tools of participation provided by the laws of Ukraine include local referendum, public comment, public hearings, request for information, citizens' communications, e-petitions, e-consultations and participatory budget (Fig. 1). The Laws of Ukraine On Local Self-Government in Ukraine, On Citizens' Appeals, On Access to Public Information, On Regulation of City Planning Activity and the Law of Ukraine On Strategic Environmental Assessment provide the legal framework for participation tools in urban development and planning. Some tools in the past few years have become an important basis for involving citizens in the place-making processes and local communities development. Despite the variety of the tools, their different objectives and impacts, participation tools significantly influence (implicitly or explicitly) the process of urban transformations, encouraging its transparency and accessibility as well as interest and communication on urban planning issues, development and strengthening of the new values behind planning and spatial changes. Regulatory developments of participation tools, which are being actively undertaken since 2015, is the same "first (technical) step for... [citizen] involvement" (Istenič \& Kozina, 2020), while increasing the variety of tools allows not only to "address different population groups" (Istenič \& Kozina, 2020), but also contributes to development of participation and collaboration at different stages of urban restructuring. An overview of the main participation tools in regard to the urban restructurings and developing the interactions between actors concerned is given below.

Public hearings as a part of the overall process of urban planning documentation development and approval provide an important platform for interactions between the key interested parties: city authorities, urban planners, local businesses and citizens. Even the first version of the Law of Ukraine On the Principals of Town Planning in 1992 provided for "participation of citizens and associations of citizens in the consideration of urban

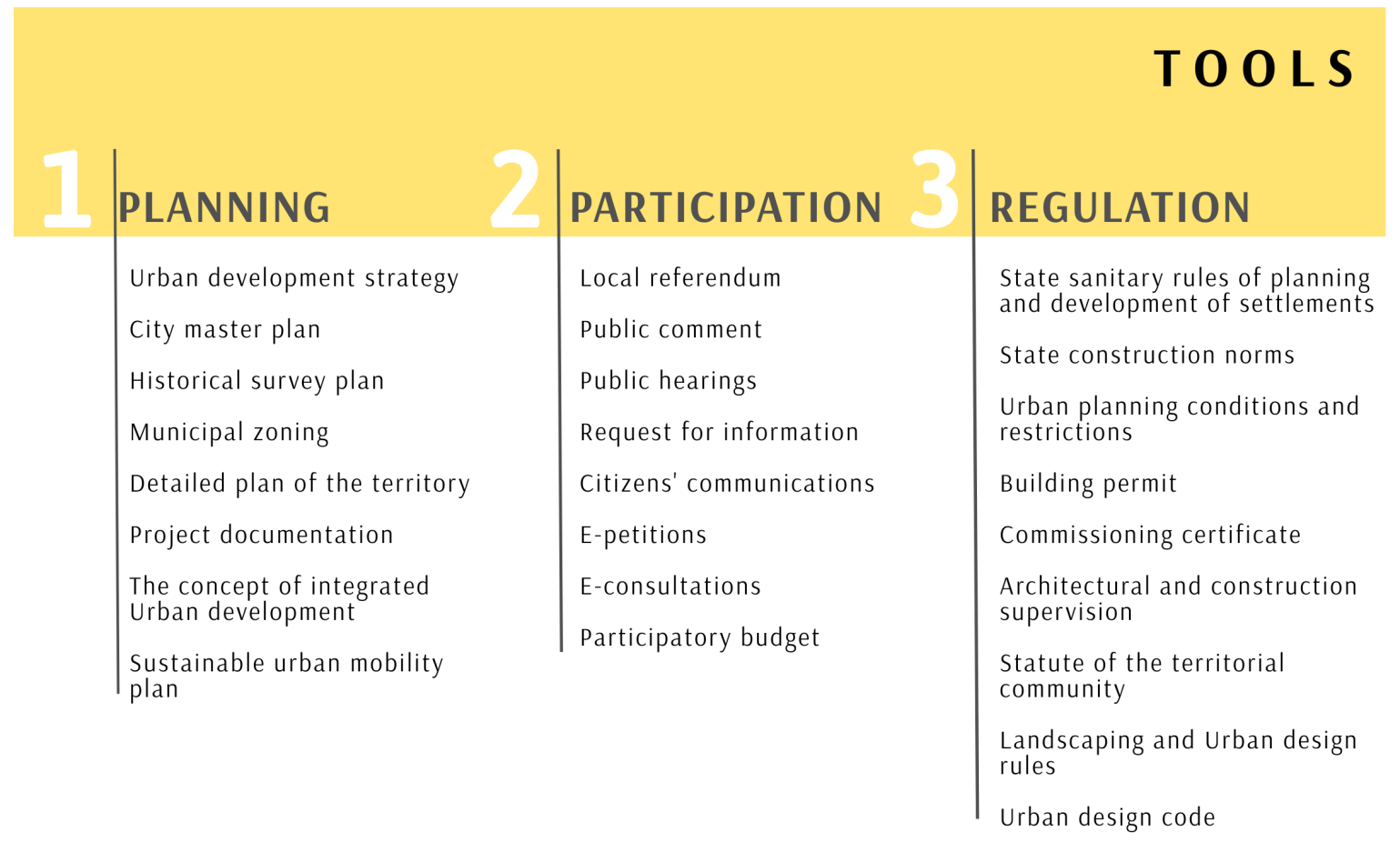

Fig. 1. The main tools for governing urban transformations (source: elaborated by the authors) 
planning documentation, projects of individual facilities and the submission of appropriate proposals" (Закон України Про основи ..., 1992). This formal requirement remains unchanged in 2020. Article 21 of the Law of Ukraine On Regulation of City Planning Activity with a promising title "Public comment on the consideration of public interests", however defines that "Draft projects of town-planning documentation of the local level, such as masterplans, zoning, detailed plans of territories, developed in a due course, should be publicly discussed". While at first glance it looks as an important commitment, this norm remains one of the most controversial in terms of public participation in urban planning and making public hearings an effective tools of the urban policy. In practice, debates on the planning documentation that is already developed, regardless of their form, leave very little chance for any significant changes in such documentation, which makes this tool more declarative and formal, serving for advertisement, but not for advising. Discussing the drafts of urban planning documentation at the very last minute further exacerbates the situation with low engagement and weak collaboration, when public hearings are mainly used to legitimize necessary decisions. While some actors expect public hearings to act as a platform for communication between different interested parties to balance their interests, however in practice, both the legislative framework and the ongoing practice of holding public hearings typically are focused on the "informing", at best. This corresponds with entry level of participation (see Cilliers \& Timmermans, 2014 for adapted participation ladder), but mostly is not aimed at achieving the next levels - consult, advise, cooperation and finally equal rights.

E-petitions are among the relatively new tools of participation designed to ensure the interaction between citizens and authorities, this is a form of citizens' communications that appeared in 2015 by changing the Law of Ukraine On Citizens' Appeals. Since e-petitions might be submitted to local authorities, as this is stipulated by the law, they often address the urban development issues, particular urban spaces and concepts of their development. In this regard e-petitions play an important role as a tool, strengthening publicity and attracting attention of citizens, civil society organizations, experts and opinion leaders to certain aspects of (un)desirable transformation of urban spaces.

Public budget as well as e-petitions, is a relatively new tool for strengthening local democracy in Ukraine (introduced in 2015), aimed at increasing the public participation in the budget process at the local level. Since each local authority approve the provisions on the public budget by their own decision, this creates slightly different conditions for the implementation of projects in different cities, including the funding, the level of competition and the main areas of project implementation. It should be noted that almost in all cities where this tool is introduced it had become an important tool for the transformation of urban space at the local level and also implementation of promising urban initiatives and projects. In view of this, the public budget should be considered as one of the workable tools for the transforming urban spaces, which, moreover, is based on horizontal integration, promotion of the project ideas, their competition and consolidation of efforts to implement the project. From this perspective and also bearing in mind how popular the public budget became in a relatively short period, the public budget is among the important local tools for transforming urban spaces, their quality and conceptions.

Despite the emergence of new participation tools, their developing and improving, which also contributes to the institutional development, however, their role in urban transformations in (post)transitional reality remains rather ambiguous. This applies both to the performance of the particular tools, their ability to ensure the expected results, progress in achieving the declared goals, and also reinforcing the values of participatory governance, along with their ability to promote urban renewal and urban restructurings. Using the results of in-depth interviews in the case cities with the main actors concerned, in the following paragraph we would critically analyze the tools of planning and participation in terms of their impact on the transformation of urban spaces in (post)transitional perspective.

\section{Analysis of the planning and participation tools performance: the case of Kherson and Kryvyi Rih}

The local context of using planning and participation tools is analyzed through the experience of two Ukrainian regional centers: Kherson and Kryvyi Rih, which are quite different in terms of the city size (both by the population and area), economic structure and character of the urban environment. This allows to interpret urban renewal and restructuring processes in diverse urban contexts and tools that are commonly used for these purposes.

Kryvyi Rih, the "steel heart of Ukraine", is a center of iron ore industry and ferrous metallurgy with consequent degradation of environmental quality and effects on economy and urban development. There is developed a unique planning structure, where certain areas are poorly integrated with each other, the quality of infrastructure, including transportation, is low. In addition there is high level of air pollution, and population decline is taking place (in 2011-2020 the population decreased from 663.5 to 619.3 thous. persons) (Чисельність населення..., 2011; 2020). Combined, these make corresponding effect on the urban space as well as attempts to modify it, which mainly occur on a local scale, have just begun and are often associated with small initiatives.

Kherson, a regional center in the south of Ukraine and one of the oldest seaports in the country, is located at the mouth of the Dnipro river in a predominantly agricultural environment. The existence of the port has contributed to the development of shipbuilding and ship repair, as well as industries based on imported raw materials, in particular, the textile industry; the agricultural environment, in turn, has contributed to the development of agricultural machinery and food industry. However, the transitional period and the decline in production have exacerbated the challenges of city peripherality, urban environment and infrastructure degradation, population decline and migration outflow (population decreased from 299 thous. persons in 2011 to 287 thous. in 2020). It is against this background, that any process of urban renewal and transformation of urban space, both in Kherson and 
Kryvyi Rih, seems to be very desirable and expected. On the other hand, however, urban renewal is also very challenging in terms of initiative, funding and outcomes. Therefore, assessment of the available tools facilitating urban transformations by different actors involved (in line with the goals and expected results, accessibility of the tools, widespread practices and results achieved) is an essential step for rethinking both the tools and their performance in the light of urban renewal processes.

Analysis of using the planning and participation tools is based on 25 in-depth interviews with local authorities and politicians, local experts, journalists, activists, members of influential local civil society organizations. This allows to evaluate all the tools facilitating urban renewal from the perspective of those actors who regularly deal with them and also critically rethink the performance of these tools. Below the most important criteria of the tools performance will be examined in view of assessments given by different actors in their interviews.

It is particularly important to note that when analyzing the planning tools for Kryvyi Rih, Kherson or any other case we have to consider a broader context whereby this planning process have taken place, and also to keep in mind the overall transitional "planning culture" in which searching for a new place of the planning tools continued quite a long time, and is still continuing when speaking about Ukraine.

The last Soviet master plan of Kryvyi Rih was approved by the Resolution of the Council of Ministers of the Ukrainian SSR on December 19, 1986 and was aimed at "further growth of Kryvyi Rih" in territorial, demographic and industrial dimensions as a center of mining, metallurgy, and machinery. The new master plan of the post-Soviet period was approved by the decision of the Kryvyi Rih City Council on December 21, 2011 and is designed for the period up to 2030, although the procedure for its developing began already in 2005 in accordance with city program of urban planning activities approved in 2004. In 2013, the municipal zoning of Kryvyi Rih was approved, and updating of zoning was launched in 2020 in accordance with changes made to the city program of urban planning activities in 2019. The Department of City Planning Activity Regulation and Land Management of the Kryvyi Rih City Council is expecting that "this updating will allow to improve the use of the urban territory under the current situation, to create more favorable conditions for attracting investment in construction, to meet the interests of urban community in urban developments, will contribute to providing employment opportunities and improving the infrastructure" (Повідомлення..., 2020). At the same time, the Department recognizes the need to update the zoning plan, given the "need to take into account the planning decisions of previously approved detailed plans of the territory..., by which zoning plan was amended" (Повідомлення..., 2020). This situation clearly reflects the overall challenge for many cities, when numerous decisions on land-use changes and other significant planning decisions are approved through the elaboration of detailed plans of the territory for a variety of patches in the city. Under these circumstances master plans or even zonings are loosing their relevance and applicability in a short time, therefore, cannot act as a tool for transformation the urban space and implementing the initial targets.

The last Soviet master plan of Kherson was approved by the Resolution of the Council of Ministers of the Ukrainian SSR on May 30, 1984. It suggested the "further growth of the city of Kherson as an important industrial and cultural center of the Kherson region, seaport and railway junction with a population of 390 thousand people for the period up to 2000" (Про генеральний план..., 1984). In comparison, the population on 1 January 2020 was 287 thousand people (Чисельність населення..., 2020). Under the new socio-economic reality of transition, the new master plan of Kherson was approved on December 26, 2003 by the decision of the Kherson City Council. The zoning plan was approved in 2015 and revised in 2018. At the same time, the master plan of 2003 remains the only type of urban planning documentation of the post-Soviet era, where the long-term strategy for Kherson planning and development is provided. Even taking into account the possible revising and updating of the current master plan, this process has not yet begun, which calls into question the ability of existing master plan to remain an effective tool for spatial development nearly two decades after its adoption.

Most interviewees are quite critical of the planning tools role in urban renewal and consider them to be ineffective in this process. The majority of long-term plans, according to interviewees, remain on paper, whereas projects promising to be a highly beneficial, are implemented even when they do not comply with the master plan. Many actors share the view that urban planning documentation, in particular the master plan, is rarely used by citizens or potential investors, and local officials are almost the only users of it. Consequently, there is a big gap between the way urban development is portrayed in the master plan or zoning and the real situation: "At first glance, you can find everything in zoning, all zones are clearly identified, but there are another processes in reality, so the plan is made only because it is required by law" (In-depth interview, Kryvyi Rih, 2020). And furthermore, different stakeholders are equally critical of Kherson master plan, developed and approved almost two decades ago. In their view, the current state of affairs is quite comfortable for many people: "The more confusion, the easier it is to hand out the land plots. That's why we don't have a master plan per se, it hasn't been updated since 2003" (In-depth interview, Kherson, 2020). Thus, it is a challenging task to transform the master plan as "the main type of city planning documentation on a local level” (Закон України Про регулювання..., 2011) from a formally existing instrument into a functional tool that defines a long-term strategy for urban planning and development.

Below we take a look at some of the most common and significant participation tools in terms of their impact on the transformation of urban space. By definition, public hearings were supposed to be one of the most important collaborative tools, ensuring the interaction of all major stakeholders: local authorities, urban planners, citizens, local activists, civil society 
organizations, businesses and the media. However, in practice it is quite challenging task to bring together majority of the mentioned parties under the framework of public hearings and public discussion. Interviewees, describing their own experiences, emphasize that in most cases public hearings are arranged on formal grounds, and ensuring coordination between interested parties is not the objective. Therefore, the outcome of such hearings is well known to most well in advance. That is why interest in public hearings is rather low, many actors do not regard them to be a way to influence decision-making, so citizens quite often consider their participation as meaningless: "There is no sense to participate in this, all decisions have been made" (In-depth interview, Kryvyi Rih, 2020). And while most interviewees are quite critical of the public hearings impact on the transformation processes, nevertheless, various actors recognize their importance as a tool to provide participation. Also, as noted by activists, "Sometimes it becomes possible to add specific requirements to the technical documentation during the public hearings and then to control how they are implemented" (In-depth interview, Kryvyi Rih, 2020).

New e-democracy tools, that are becoming quite popular among citizens and activists, include e-petitions, which can be used as an influential communication tool in the search of solutions to accelerate urban renewal and draw attention to the particular urban spaces. Since the issuance of the petitions and the process of collecting signatures is regulated by the Statute of the territorial community, the thresholds for the consideration of petitions in Kherson and Kryvyi Rih are different: 250 and 1,000 signatures of citizens respectively. Meanwhile, the number of submitted petitions in these cities differs dramatically. There are a little more than 30 petitions submitted in Kherson, while in Kryvyi Rih there are almost 300 petitions submitted since 2015. Most of them did not get the required number of signatures and should be considered as citizens' appeals. In order to strengthen the collection of signatures and ensure the compliance of the draft petitions with the procedure, the Kherson City Council developed Recommendations on the content of electronic petitions, which calls for "communication campaign" and "dialogue with the authorities". According to the Kherson City Council, a dialogue with the authorities is as follows: "There should be found a compromise, complex solution benefiting everyone. It is important for local authorities to have a reputation to uphold, and for people to have their problems resolved" (Рекомендації...). Both recommended dialogue and a specific vision of arguments for each party essentially reflect one major critique of e-petition as a collaborative tool, which is the formal consideration by local authorities the issues raised in a petition. At the same time, however, this tool allows to attract public attention and engage the media on issues of landscaping and urban design, interests of particular users of urban space and also providing services in urban neighborhoods.

Participatory budgeting as a tool intended to enhance public participation in the budget process at the local level is increasing more and more and is gaining support as a way to implement public initiatives, including urban design and urban renewal. Moreover, it is one of the few tools that is changing rapidly along with improving its regulations; a number of good practices are emerging, the implemented projects themselves are becoming more original and also increasingly focused on the particular urban spaces. From this perspective, the experience of project application development, creating a motivated team, promotion of project ideas and collaboration with responsible local executive bodies are no less important objectives than project implementation itself.

The participatory budget in Kryvyi Rih was launched in 2016 when first 46 projects were submitted and implemented (in particular, $41 \%$ of them in the field of energy saving) (hereinafter data are from Платформа реалізації ідей...). In contrast, two years later, in 2018, 145 projects were submitted, and 47 were implemented (mainly in the field of education, physical culture, and sports), 56.6 thousand people took part in the voting. In 2020, 124 projects were submitted, 50 winning projects were selected (52\% in the category of municipal projects), and 80.7 thousand people took part in the voting. Critically evaluating this tool at the early stages, activists describe it, as follows: “... simple and even primitive projects, such as replacement of windows and doors. In the early years it was a tool for repairing school and kindergarten buildings. Projects seem to be prepared by using a photocopier. But some ideas happen to be good. For instance, a play area was arranged in the courtyard of the school not far from here. But it is closed. It gets open only during the breaks. Children don't go there" (In-depth interview, Kryvyi Rih, 2020). However, the regulation of this tool has been significantly improved in recent years. Currently in Kryvyi Rih projects are competing within several different thematic categories and depending on the scale (large and small projects). This provides an opportunity for implementation of the small initiatives in the field of landscaping, park areas renewal and many others. With this in mind, the participatory budget, especially considering its regularity, competitiveness, financial support, is becoming an important tool not only for a collaboration but also for urban renewal, it helps to bring together citizens around this task, to demonstrate the possibility of its implementing and develop horizontal communication around the idea of transforming the urban space.

In view of the experience of using the planning and participation tools for the aims of urban transformations, the critical perception of these processes and their outcomes by various actors, as well as disproportionate impact of the parties, the issue of the performance of the tools should be addressed. This should be accompanied by a number of important questions, aimed at further rethinking of urban governance and urban policy in (post) transitional perspective as well asthe main tools in urban planning and urban development, especially those which contribute to making urban renewal in a more democratic way. The most important questions are as follows. To what extent the available planning and participation tools are contributing to the needs of urban renewal? Do the performance and impact of particular tools differ in various local contexts? What are the main barriers to improving their effectiveness? 
Based on the results of in-depth interviews with various actors, a summarized assessment of the main planning and participation tools is proposed, using several criteria (Fig. 2). The main criteria for the analysis of the performance include: the compliance of the tools (by targets, content and procedures) with the needs of urban renewal, accessibility for the public, awareness of the content and evolution of the tool - its ability to change and respond to the new developments. Particular tools differ significantly upon these criteria, as could be seen from the interviews with various actors and their assessments. For instance, despite the role of the planning tools in shaping the strategy for urban development and planning, as provided by law, in practice planning tools rarely provide it, and their focus on the needs of urban renewal is often assessed by many actors as rather low. On the contrary, the tools of participation, which are not inherently focused on the urban transformations, in practice are often used for these purposes, in particular relatively new tools, such as participatory budget, e-petitions, etc. This is also relevant when using second criteria and comparing the accessibility of urban planning documentation with new participation tools. In most cases, the latter are much more accessible to the public. Therefore, it is not surprising that their impact on the transformation of particular urban spaces is sometimes comparable or even higher than the impact of planning tools. In most cases, the main actors are much better informed about the procedure for using the participatory budget or other participation tools than the master plan or zoning, which is certainly a consequence of restricted use of urban planning documentation for a long time. This barrier remains a part of the legacy of the previous era and requires to change the discourse on planning documentation or even to develop a new philosophy of its perception in (post)transitional reality.

\section{Conclusions}

The coexistence of several different trends could be detected when analyzing the using of tools and specific local practices both in regard to the ways of governance, institutional development and methods of communication. On the one hand, there is a declared trend towards democratization and increasing the transparency of tools and procedures. On the other, partially updated and entirely new tools typically have little impact on urban transformations, which are mostly the result of multiple chaotic processes. On the one hand, there is a tendency for rethinking the planning tools and a growing need for them. On the other, the process is so slow that it discredits both the planning tools and also policies with institutions involved. On the one hand, new tools for participation are emerging, improving and evolving. On the other, the local success of particular tools of participation and collaboration cannot create a sense of trust and cooperation between different stakeholders, including local authorities. These trends in the best way reflect the situation of "half measures" (Cleary, 2016) with implemented policies.

It is from this perspective that the urban planning system as well as urban transformations resulted from complicated processes in transitional societies, where

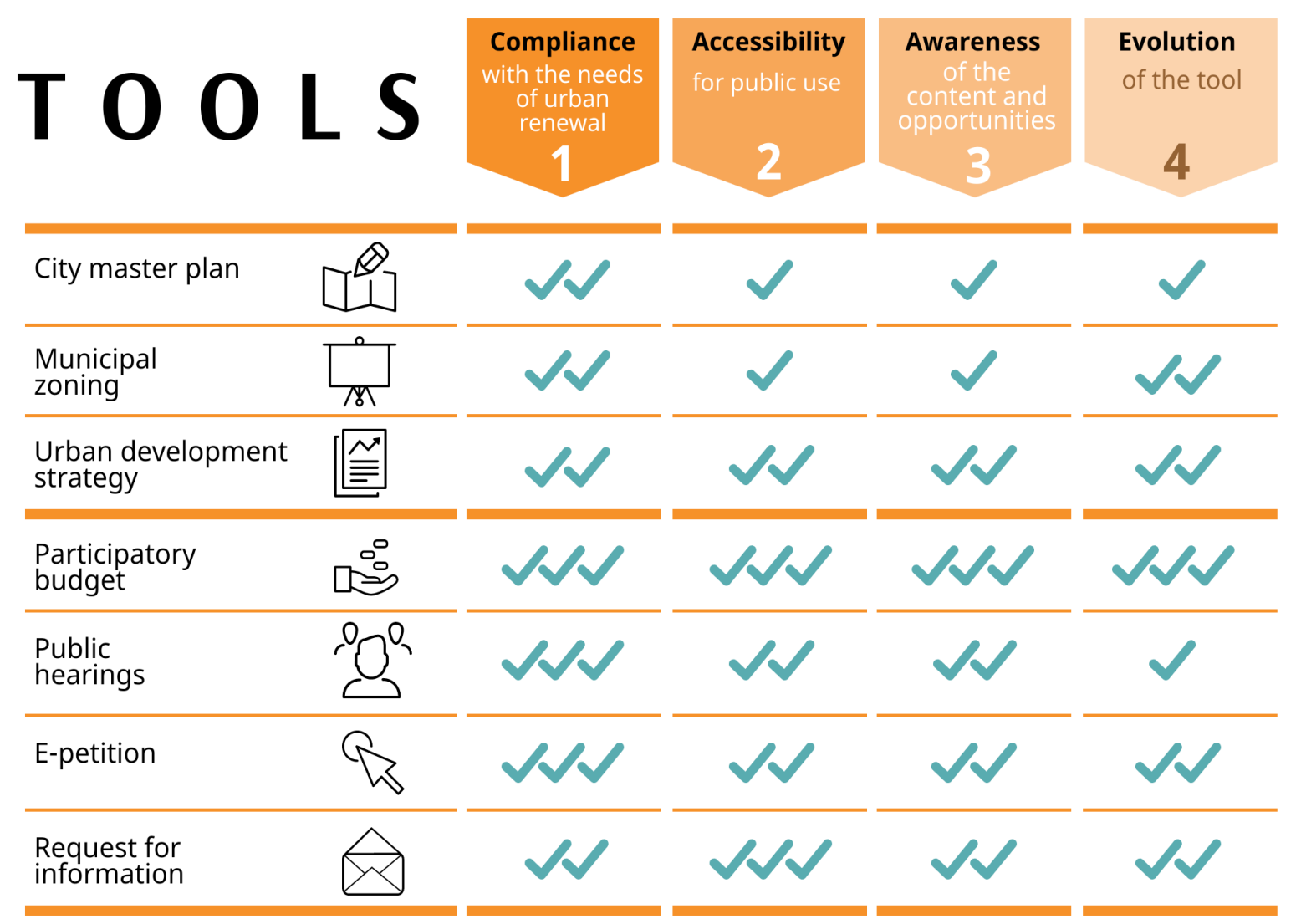

Fig. 2. Summarized assessment of the main planning and participation tools performance (source: elaborated by the authors based on in-depth interviews) 
shifting paradigms in urban planning overlapped with many other trends aimed at transforming the urban governance. Therefore, in some cases the emergence of new participation tools caused the excessive enthusiasm about them and subsequent replacement of other strategic tools of urban policy, while in other cases, this has resulted in complete indifference both on the particular tools and any interactions with local authorities. This to some extent helps to explain how communication in urban planning and tools providing it are "transformed within a context of power" (Fainstein, 2005) for the case of a (post)transitional reality, where the institutional and social heritage of the previous era is almost as strong as the attempts to transform it.
The disappointment in the performance of both particular tools and related institutions, which is quite typical for the (post)transitional reality and also detected for analyzed cases, should be considered from the perspective of continuing institutional development, when tools, norms and procedures are critically reconsidered and tested all the time (just as they are constantly critically reconsidered for other planning contexts - for instance, Legacy, 2017; Meléndez \& Parker, 2019). On the other hand, thiscould be used as a basis for the implementation of "more place-focused public policy" (Healey, 1999), the demand for which is particularly evident in recent years.

\section{References}

Головаха, Е., Панина, Н. (2001). Постсоветская деинституционализация и становление новых социальных институтов в украинском обществе. Социология: теория, методы, маркетинг, 4, 5-22. [Golovakha E., Panina, N. Post-Soviet deinstitutionalization and development of new social institutions in Ukrainian society]

Закон України Про основи містобудування від 16.11.1992 № 2780-XII (Редакція станом на 16.10.2020). Режим доступу: https://zakon.rada.gov.ua/laws/show/2780-12/ed20201016\#Text [Law of Ukraine On Basics of townplanning]

Закон України Про планування і забудову територій від 20.04.2000 № 1699-III (Редакція станом на 20.04.2000). Режим доступу: https://zakon.rada.gov.ua/laws/show/1699-14/ed20000420\#Text [Law of Ukraine On planning and development of territories]

Закон України Про регулювання містобудівної діяльності від 17.02.2011 № 3038-VI (Редакція станом на 01.12.2020). Режим доступу: https://zakon.rada.gov.ua/laws/show/3038-17\#Text [Law of Ukraine On regulation of town-planning activity]

Маруняк Є. О. (2014). Територіальне (просторове) планування: зміст, еволюція та основні сучасні напрями. Український географічний журнал, 2, 22-31. [Marunyak Ye. Territorial (spatial) planning: content and evolution of major modern trends]

Мезенцев К. В., Денисенко О. О. (2018). Міста на постсоціалістичномупросторі: підходи до концептуалізації та місце в урбаністичномудискурсі. Український географічнийжурнал, 4, 16-24. [Mezentsev K.V., Denysenko O.O. Cities in post-socialist space: approaches to conceptualization and placing in urban discourse]

Палеха Ю. М., Олещенко А. В. (2016). Містобудівна документація у державах Європейського Союзу і в Україні: порівняльний аналіз. Досвід та перспективи розвитку міст України, 30, $50-57$ [Palekha Yu., Oleshchenko A. Urban planning documentation in EU states and Ukraine: comparative analysis]

Платформа реалізації ідей для покращення твого міста: Кривий Ріг. Режим доступу: https:/gb.kr.gov.ua [A platform for implementing ideas to improve your city. Kryvyi Rih.]

Повідомлення про початок процедури розгляду та врахування пропозицій громадськості у проекті містобудівної документації “Актуалізація плану зонування м. Кривий Ріг та звіті про стратегічну екологічну оцінку” від 9.11.2020. Режим доступу: https://kr.gov.ua/ua/news/pg/91120811087058_s/ [Notification of the beginning of the procedure of consideration and integration of public proposals in the draft of urban planning documentation "Update of the zoning plan of Kryvyi Rih and Report on strategic environmental assessment" issued on 9 November 2020].

Про генеральний план розвитку міста Херсона. Постанова Ради Міністрів УРСР від 30.05.1984 №231. [On the general plan of Kherson. Resolution of the Council of Ministers of the Ukrainian SSR on May 30, 1984, № 231].

Про генеральний план розвиткуміста Кривого Рога Дніпропетровської області. Постанова Ради Міністрів УРСР від 19.12.1986 №435. [On the general plan of Kryvyi Rih, Dnipropetrovsk region. Resolution of the Council of Ministers of the Ukrainian SSR on December 19, 1986, № 435].

Рекомендації щодо змісту електронних петицій. Режим доступу: http://www.city.kherson.ua/articles/ elektronni-peticiyi-2 [Recommendations on the content of electronic petitions].

Чисельність наявного населення України на 1 січня 2020 p. Режим доступу: http://www.ukrstat.gov.ua/druk/ publicat/kat_u/publnasel_u.htm [Number of available population as of January 1,2020].

Чисельність наявного населення України на 1 січня 2011 p. Режим доступу: http://www.ukrstat.gov.ua/druk/ publicat/Arhiv_u/13/Arch_nnas_zb.htm [Number of available population as of January 1, 2011].

Cilliers, E. J., \& Timmermans, W. (2014). The importance of creative participatory planning in the public placemaking process. Environment and Planning B: Planning and Design, 41(3), 413-429.

Cleary, L. (2016). Half measures and incomplete reforms: the breeding ground for a hybrid civil society in Ukraine. Southeast European and Black Sea Studies, 16(1), 7-23. 
Durnová, A. (2021). Czech postcommunist trouble with participatory governance. Toward an analysis of the cultural agency of policy discourses. Policy Studies, 42(1), 80-97.

Fainstein, S. S. (2005). Planning theory and the city. Journal of Planning Education and Research, 25(2), 121-130.

Ferenčuhová, S., \& Gentile, M. (2016). Introduction: Post-socialist cities and urban theory. Eurasian Geography and Economics, 57(4-5), 483-496. 457-471.

Fischer, F. (2012). Participatory Governance: From Theory to Practice. The Oxford Handbook of Governance,

Friedmann, J. (2005). Globalization and the emerging culture of planning. Progress in Planning, 64(3), 183-234.

Friedmann, J. (2010). Place and place-making in cities: A global perspective. Planning Theory \& Practice, 11(2), 149-165.

Fung, A., \& Wright, E. O. (2003). Deepening democracy: Institutional innovations in empowered participatory governance. Verso. 247.

Golubchikov, O. (2004). Urban planning in Russia: towards the market. European Planning Studies, 12(2), 229-

Golubchikov, O., Badyina, A., \& Makhrova, A. (2014). The hybrid spatialities of transition: Capitalism, legacy and uneven urban economic restructuring. Urban Studies, 51(4), 617-633.

Grava, S. (1993). The Urban Heritage of the Soviet Regime. The Case of Riga, Latvia. Journal of the American Planning Association, 59(1), 9-30.

Gualini, E., \& Bianchi, I. (2015). Space, politics and conflicts: A review of contemporary debates in urban research and planning theory. In Planning and Conflict: Critical Perspectives on Contentious Urban Developments. Routledge, 37-55.

Healey, P. (2010). Introduction: The transnational flow of knowledge and expertise in the planning field. In Crossing Borders: International exchange and planning practices. Routledge, pp. 1-26.

Healey, P. (1999). Institutionalist analysis, communicative planning, and shaping places. Journal of Planning Education and Research, 19(2), 111-121.

Hirt, S. A. (2005). Planning the post-communist city: Experiences from Sofia. International Planning Studies, $10(3-4), 219-240$.

Hirt, S., \& Stanilov, K. (2009). Revisiting urban planning in the transitional countries. Unpublished regional study prepared for the Global Report on Human Settlements.

Hirt, S., Ferenčuhová, S., \& Tuvikene, T. (2016). Conceptual forum: The "post-socialist” city. Eurasian Geography and Economics, 57(4-5), 497-520.

Huxley, M., \& Yiftachel, O. (2000). New paradigm or old myopia? Unsettling the communicative turn in planning theory. Journal of Planning Education and Research, 19(4), 333-342.

Innes, J. E., \& Booher, D. E. (2018). Planning with Complexity: An Introduction to Collaborative Rationality for Public Policy. Routledge.

Istenič, S. P., \& Kozina, J. (2020). Participatory Planning in a Post-socialist Urban Context: Experience from Five Cities in Central and Eastern Europe. In Participatory Research and Planning in Practice (pp. 31-50). Springer, Cham.

Legacy, C. (2017). Is there a crisis of participatory planning? Planning Theory, 16(4), 425-442.

Meléndez, J. W., \& Parker, B. (2019). Learning in participatory planning processes: Taking advantage of concepts and theories across disciplines. Planning Theory \& Practice, 20(1), 137-144.

Neugebauer, C., Semenov, A., Denysenko, O. (2020): Urban activism and planning in Ukraine and Russia. In T. Darieva, C. Neugebauer (eds.), Urban Activism in Eastern Europa and Eurasia. Strategies and Practices. DOM Publishers, pp. 138-200.

Peck, J., Theodore, N., \& Brenner, N. (2009). Neoliberal urbanism: Models, moments, mutations. SAIS Review of International Affairs, 29(1), 49-66.

Roy, A. (2011). Urbanisms, worlding practices and the theory of planning. Planning Theory, 10(1), 6-15.

Sýkora, L. (2006). Urban development, policy and planning in the Czech Republic and Prague. In Spatial Planning and Urban Development in the New EU Member States: From Adjustment to Reinvention. Ashgate: Aldershot, pp. 113-140.

Sýkora, L., \& Bouzarovski, S. (2012). Multiple transformations: Conceptualising the post-communist urban transition. Urban Studies, 49(1), 43-60.

Tsenkova, S. (2006). Beyond transitions: Understanding urban change in post-socialist cities. In The Urban Mosaic of Post-Socialist Europe (pp. 21-50).

Tsenkova, S. (2014). Planning trajectories in post-socialist cities: patterns of divergence and change. Urban Research \& Practice, 7(3), 278-301.

Van Assche, K., Verschraegen, G., \& Salukvadze, J. (2010). Changing frames: Citizen and expert participation in Georgian planning. Planning Practice \& Research, 25(3), 377-395.

Van Wymeersch, E., Oosterlynck, S., \& Vanoutrive, T. (2019). The political ambivalences of participatory planning initiatives. Planning Theory, 18(3), 359-381.

Vujošević, M., \& Nedović-Budić, Z. (2006). Planning and societal context - The case of Belgrade, Serbia. In The Urban Mosaic of Post-Socialist Europe (pp. 275-294). 